\section{Studying on the Sedimentary Control Function Affect by the Tectonic Evolution of Raoyang Sag in Upper the First Member of Shahejie Formation in Dawangzhuang Oilfield}

\section{Guo Fajun ${ }^{1}$, Zhang Shujuan ${ }^{1}$, Yang Xudong ${ }^{2}$, Xiejun $^{2 \star}$, Chen Xiaoqin ${ }^{1}$ and Zhou Kai ${ }^{1}$}

${ }^{1}$ Research Institute of Exploration and Development of Huabei Oilfield Company, Renqiu, Hebei, China

${ }^{2}$ Shandong University of Science and Technology, Qingdao, Shandong, China

\begin{abstract}
This paper is based on regional tectonic evolution, through the study of the migration process of the subsidence center inside the sag, to explore the control of the provenance direction and sedimentary facies types in the Dawangzhuang area around the sedimentary period of the Upper Shahejie Formation, establishing a depositional model of upper the first member of Shahejie Formation. The results show that the subsidence center of the first member of Shahejie Formation is located in the northeast of the study area, and the Zhaohuangzhuang buried hill is initially developed, simultaneously, the source of the northwest Gaoyang low bulge and the eastern Xianxian uplift are respectively blocked by the suning and the concave middle buried hills, which have little impact on the study area. During the sedimentation from upper the first member of Shahejie Formation to Dongying Formation, as the area of the uplifted lake basin of the fault depression rapidly shrinks, the topography gradually flattens and the sedimentary facies extend continuously. The source of upper the first member of Shahejie Formation in the Dawangzhuang area comes from the Shenze low bulge in the southwest direction, and the main sedimentary
\end{abstract}

*Corresponding author: Xiejun, Shandong University of Science and Technology, Qingdao, Shandong, ChinaTel:+86 13708962993; E-mail: xiejun0532@ sdust.edu.cn

Supported by the Natural Science Foundation of China (51674156) \& Major Project "Research and Application of Key Technologies for Sustainable and Stable Production Exploration and Development in Huabei Oilfield" (2017E-15)

Citation: Fajun G, Shujuan Z, Xudong Y, Xiejun, Xiaoqin C, et al. (2019) Studying on the Sedimentary Control Function Affect by the Tectonic Evolution of Raoyang Sag in Upper the First Member of Shahejie Formation in Dawangzhuang Oilfield. J Atmos Earth Sci 3: 014.

Received: November 21, 2019; Accepted: December 10, 2019; Published: December 17, 2019

Copyright: @ 2019 Fajun G, et al. This is an open-access article distributed under the terms of the Creative Commons Attribution License, which permits unrestricted use, distribution, and reproduction in any medium, provided the original author and source are credited. facies type is the delta front sub facies. The results of this study have potential application value for the development and evaluation of later reservoirs.

Keywords: Dawangzhuang area; Raoyang sag; Sedimentary facies; Shahejie Formation; Tectonic evolution

\section{Introduction}

The first member of Shahejie Formation $\left(\mathrm{Es}_{1}\right)$ in Raoyang sag has good oil-bearing properties in the Dawangzhuang area. With the deepening of oilfield exploration and development, it is found that the oil and gas accumulation in the study area is not only controlled by the structure and faults, but also by the sedimentary facies. However, the predecessors still have different opinions on the sedimentary facies types in the Dawangzhuang area. Zhu Mao et al believe that during the period of the first member of Shahejie Formation $\left(E_{1}\right)$, as the regional uplift is strengthened, the lake becomes shallower and smaller, forming a depositional system of shallow-water meandering river delta [1]. According to the chemical analysis of organic elements, Huang Zhijia et al believed that the sedimentary environment of the Dawangzhuang area was a braided river delta deposit [2]. According to the geomorphological characteristics and petrological signs, Zhang Wei et al believe that the Shahejie Formation developed a braided river delta-lake sedimentary system [3]. It can be seen that many scholars have different views on the types of sedimentary facies. Therefore, it is necessary to conduct a study on the sedimentary facies of the first member of Shahejie Formation in the Dawangzhuang area. Wang Xiaotong et al believe that the evolution of the bulge and fault will control the evolution of the peripheral basin [4], the study of the evolution of buried hills in the depression of Raoyang Sag this time clarified its restrictive effect on sedimentary evolution in Dawangzhuang area.

\section{Geological Survey}

The Raoyang sag is a sub-tectonic unit formed by the Paleogene. It is located in the southeast of the Jizhong depression and has an obvious asymmetric structure of the east-southwest super-symmetry [5]. The northern part of the Raoyang sag is bounded by the Baxian sag, the south is close to the Shenze and Xinhe bulges, the eastern part is bounded by the Xianxian bulge, and the west isadjacent to the Gaoyang low bulge. The Raoyang sag contains three sub-tectonic units from west to east, namely: Lixian Slope Belt, Dawangzhuang-Sunning-Rennan-Renxi depression, middle buried hill and eastern fault structural belt [6], the favorable areas for oil and gas development in the Jizhong depression. The Dawangzhuang area of the study area is located in the south-central part of the Raoyang Sag, adjacent to the Dawangzhuang tectonic belt (Figure 1). During the period of upper the first member of Shahejie Formation in the Dawangzhuang area, it was in the uplifting and extinction period of the fault depression in the Raoyang sag. Under the control of the Dawangzhuang East fault, the Dongying Formation stratum with better sedimentation at the root of the descending fault was gradually over thinned in the east; on the ascending disk, the thickness of the formation gradually thins from 
Citation: Fajun G, Shujuan Z, Xudong Y, Xiejun, Xiaoqin C, et al. (2019) Studying on the Sedimentary Control Function Affect by the Tectonic Evolution of Raoyang Sag in Upper the First Member of Shahejie Formation in Dawangzhuang Oilfield. J Atmos Earth Sci 3: 014.

the southwest direction and the west wing to the vicinity of the fault [7].

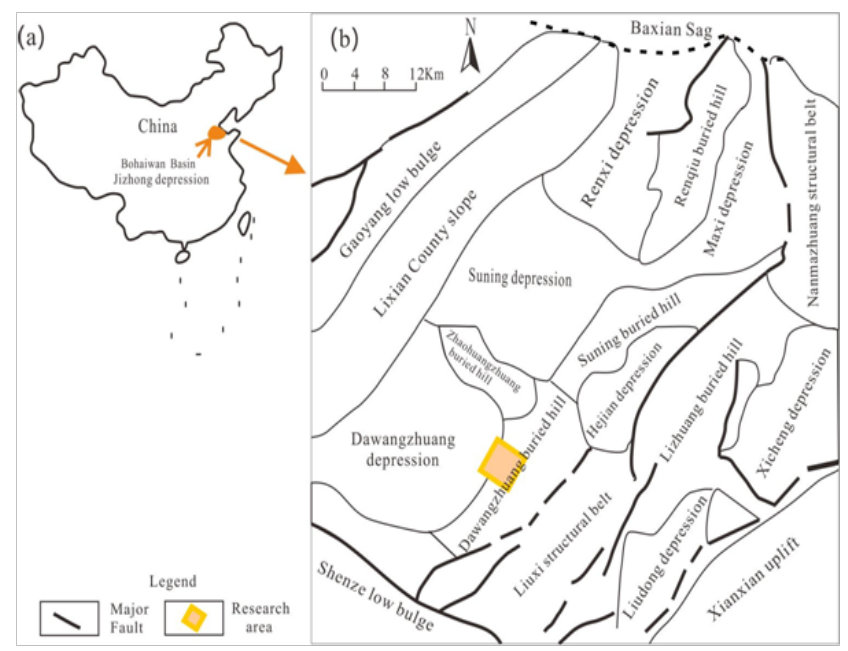

Figure 1: Current Regional tectonic map of Dawangzhuang Oilfield.

\section{Tectonic-sedimentary Evolution}

The Raoyang sag experienced five tectonic-evolution periods in the paleogene: fault depression and filling period, subsidence expansion and deep subsidence period, fault depression and uplift period, fault-breaking extension period, and fault depression uplifting and extinction period. The Raoyang sag has a thick continental stratum [8], and the sedimentary evolution process is constrained by structural factors. It can be seen from figure 2 that the Dawangzhuang area develops a series of domino-like profiles that are nearly all-easily inclined and arranged in parallel with each other at different intervals.

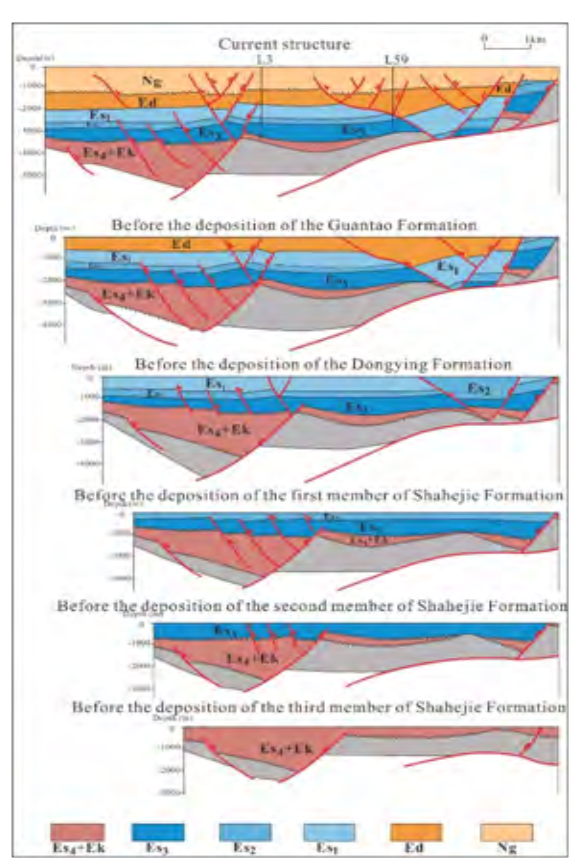

Figure 2: Tectonic evolution of the Dawangzhuang area.

\section{The influence of tectonic on the subsidence center}

During the sedimentary evolution of the paleogene, the subsidence center of the Raoyang sag continued to migrate under the influence of the tectonic effect [8]. During the sedimentary period of the kongdian Formation and the Es4, the Raoyang Sag was severely affected by the tectonic movement of the extensional fault depression, and the subsidence center was in the Sunhu area (Figure 3a). The internal gutters and buried hills in the Raoyang sag developed at different periods. Among them, the fault activity during the deposition of the third member of the Shahejie Formation was enhanced, and the activity of the concave control in the eastern part was strong. The stratum is thicker and the Lixian Slope in the west is developed. During the deposition of the lower third member of Shahejie Formation, the Raoyang Sag began to expand, and the subsidence center moved northward to the Wuqiang-Yangwuzhai area (Figure 3b). During the sedimentation of the central sub-sector of the third member of the Shahejie Formation, the Paleogene lake water first gathered in the Raoyang sag, and several settlement centers emerged in the Yuanchanglou, the Hejian depression and Sunning depression, and the Maxi depression (Figure $3 c)$. During the deposition of upper the third member of Shahejie Formation, the Raoyang sag began to gradually rise, and the subsidence center moved southward to the Sunhu-Yuke area (Figure 3d). During the sedimentary period of the second member of the Shahejie Formation, the regional uplift is more intense, and the subsidence center migrates northward to the Yangwuzhai, the Hejian depression, and the maxi depression (Figure 3e). The sedimentary period of the Lower first Shahejie Formation is the second extension period of the faulted basin, and it is also the largest period of the lake in the Raoyang sag. The structures formed during this period are mainly the liuchu and liuxi anticline, Dawangzhuang, Suning, Balizhuang covered anticline, etc. [9]. During the sedimentary period of the first member of Shahejie Formation, the center of the lake basin in the central part of the Jizhong area contracted to the Raoyang area, and the Lixian Slope in the west has also been formed. The concave middle buried hill has begun to take shape, and the Xianxian bulge gradually shrinks to the southeast. At the same time, the subsidence center moved north to Suning and maxi depression (Figure 3f). During the sedimentary period from upper the first member of Shahejie Formation to Dongying Formation, the sedimentation velocity was fast and the sedimentation velocity was slow, which caused the lake basin area to decrease rapidly.

During this period, the Xianxian bulge shrank to the southeast, theeast-off fault developed extensively, and the Zhaohuangzhuang-Xiliu structural belt gradually became larger. During the sedimentary period of the third member of Dongying Formation, the depression was once again elevated and the terrain was relatively flat, the climate was relatively dry, and the subsidence center was located in the area between the Hejian and the Suning depression (Figure 3g). During the deposition of the second member of Dongying Formation, the subsidence center moved south to the Liuxi-Dawangzhuang area (Figure $3 h$ ). During the sedimentary period of the first member of Dongying Formation, the regional tectonic movement gradually weakened, and the terrain was flattened with the quasi-plainization, and the subsidence center moved to the Hejian and the suning area (Figure 3i). 
Citation: Fajun G, Shujuan Z, Xudong Y, Xiejun, Xiaoqin C, et al. (2019) Studying on the Sedimentary Control Function Affect by the Tectonic Evolution of Raoyang Sag in Upper the First Member of Shahejie Formation in Dawangzhuang Oilfield. J Atmos Earth Sci 3: 014.

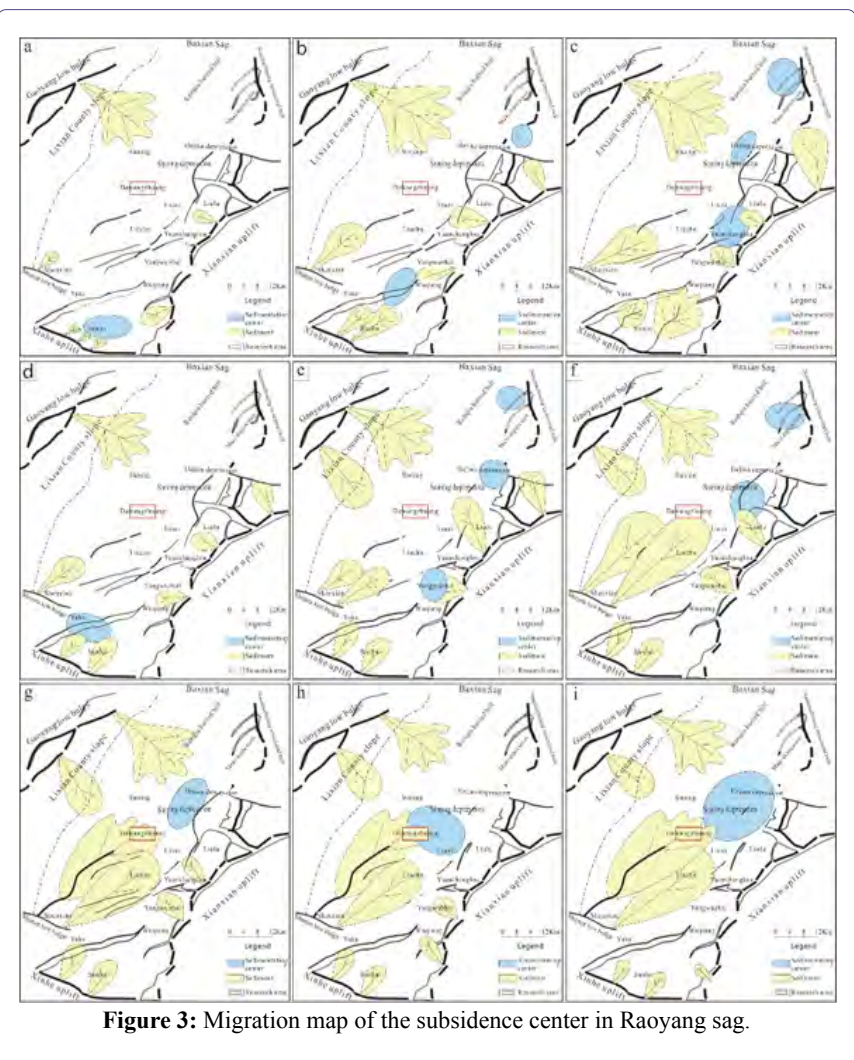

The influence of tectonic on sediment source

From the perspective of the region, the source of the first member of Shahejie Formation is mainly from the west, followed by the east. According to the analysis of comprehensive tectonic evolution characteristics, during the sedimentation of the first member of the Shahejie Formation, the subsidence center is located in the suning and maxi depressions in the northeastern part of the study area. During the sedimentary period of lower the first member of Shahejie Formation $\left(\mathrm{Es}_{1}{ }^{\mathrm{d}}\right)$, the lixian slope were formed, the suning buried hills, the Dawangzhuang and the liulu tectonic belts, and the liuchu and liuxi tectonic belts began to take shape, blocking the northwest Gaoyanglow bulge and the eastern Xianxian uplift source [10,11]. During the period from upper the first member of Shahejie Formation to Dongying Formation, the Zhaohuangzhuang buried hill gradually bulged, which had little effect on the provenance deposition in the Dawangzhuang area. In addition, the existence of the suning depression blocked the provenance deposition from the Lixian Slope. From the ratio of sand thickness to formation thickness in upper the first member of Shahejie Formation (Figure 4), the value decreases gradually from southwest to northwest, the thickness of southwest sand, and the thinness of northwest sand. The ZTR index refers to the ratio of the sum of the content of stable heavy minerals zircon, tourmaline, and rutile to the content of all transparent heavy minerals, that is, [(zircon + tourmaline + rutile) $/$ transparent heavy minerals $] \times 100 \%$. Combined with the ZTR index chart (Figure 5), it can be seen that the ZTR index of the first member of Shahejie Formation in the Dawangzhuang oilfield gradually increases from northwest to southwest. The absolute content of unstable heavy minerals in the northwest and southwest of the study area is relatively high, and the content of stable heavy minerals such as zircon, tourmaline and garnet is low. According to the comprehensive analysis, the source of upper the first member of Shahejie Formation $\left(\mathrm{Es}_{1}{ }^{\mathrm{u}}\right)$ is mainly from the Shenze low bulge in the southwest.

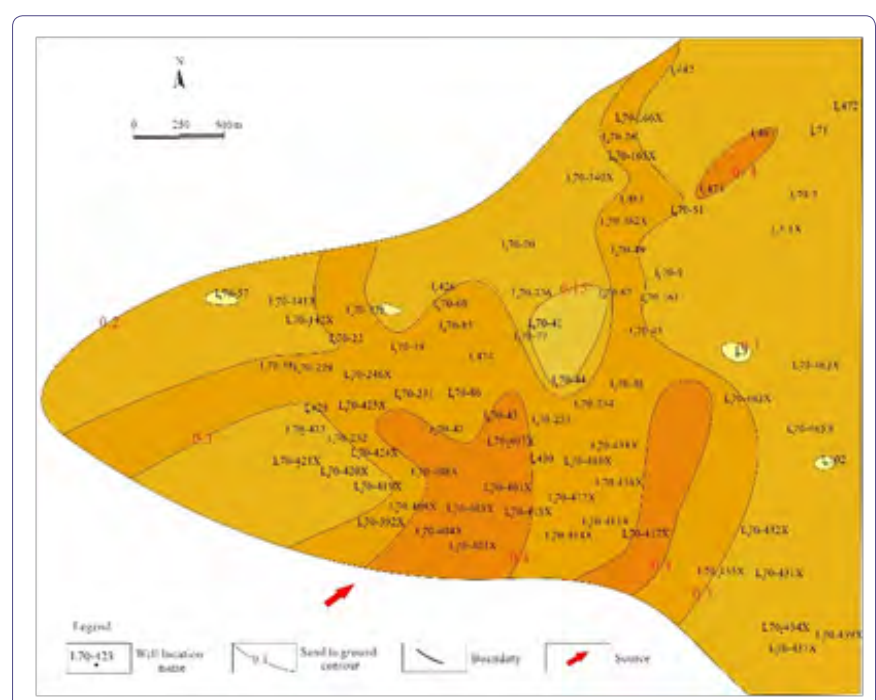

Figure 4: Sand floor ratio plan of upper the first member of Shahejie Formation in Dawangzhuang Oilfield.

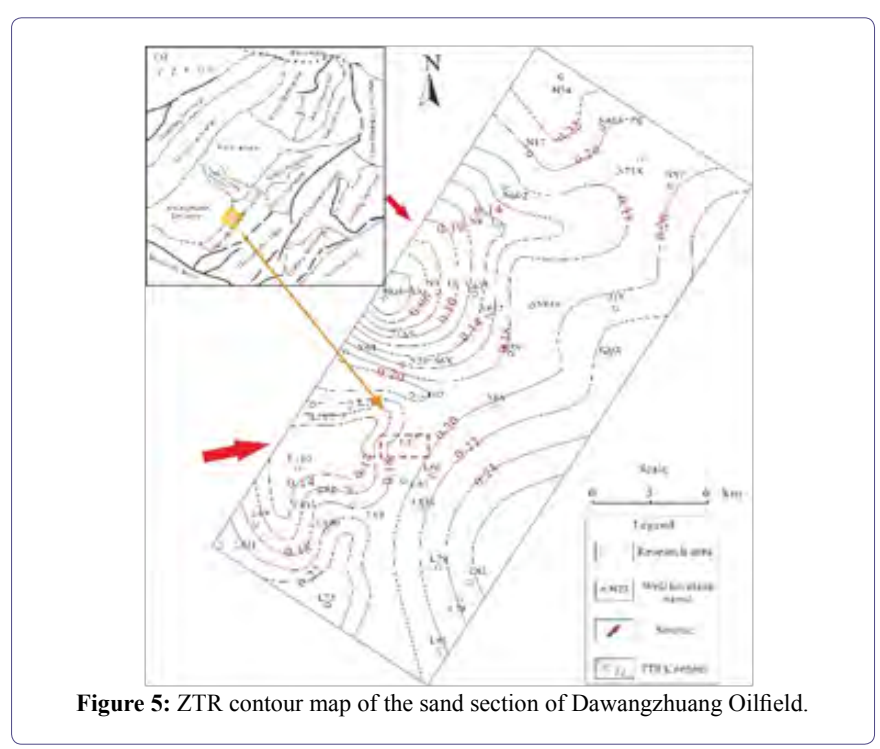

\section{Sedimentary Facies Type}

\section{Petrological characteristics}

Because the debris material is often deposited in different sizes, different degrees of sorting, roundness and degree of weathering, it can be used as a basis for explaining the hydrodynamic environment and debris removal of sediments [12]. The core observation in Dawangzhuang area shows that the rock strata in upper the first member of Shahejie Formationpart of the study area have the combination characteristics of sand-shale interbeds (Figure 6). The composition of the rock is mainly mudstone, accounting for about $46 \%$; followed by fine sandstone, about $26 \%$, and medium sandstone about $12 \%$. 
Citation: Fajun G, Shujuan Z, Xudong Y, Xiejun, Xiaoqin C, et al. (2019) Studying on the Sedimentary Control Function Affect by the Tectonic Evolution of Raoyang Sag in Upper the First Member of Shahejie Formation in Dawangzhuang Oilfield. J Atmos Earth Sci 3: 014.

Among them, the mudstone color is mostly gray, and sandstones are mostly gray fine sandstones. Upper the first member of Shahejie Formation to Dongying Formation (Figure 6). In addition, the roundness of the crumb particles is mostly round, the sorting is good, the degree of weathering is medium, and the pore cementation and particle support are obtained. It can be seen that the sandstone compositional maturity in the study area is relatively good.

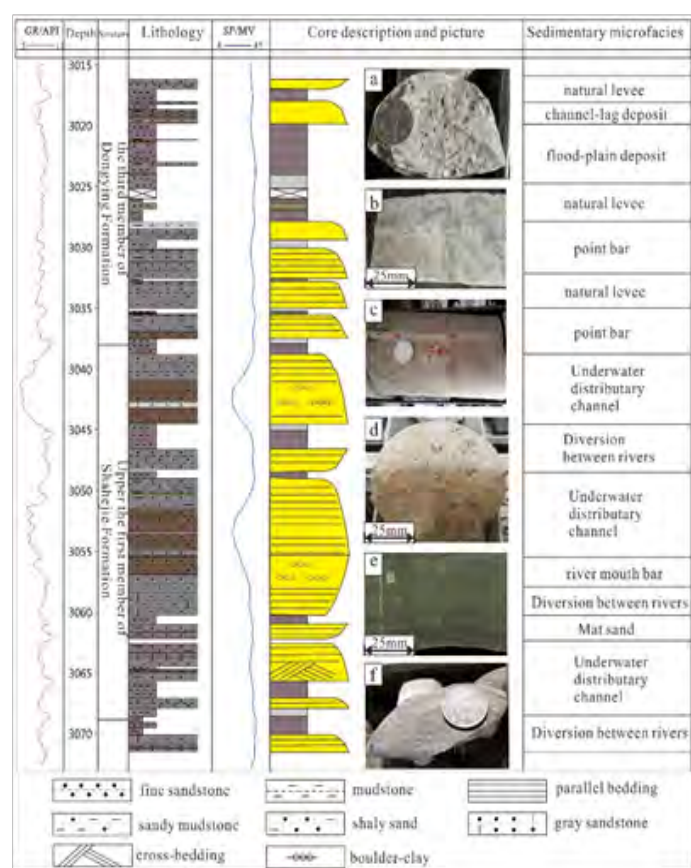

Figure 6: The single well phase diagram of L70-233.

Combined with the tectonic background analysis, during the sedimentary period of upper the first member of Shahejie Formation, there were the Suning depression and the Dawang zhuang depression in the west of the Dawang zhuang area, and the Zhaohuang zhuang buried hill was initially developed. During the deposition period of the Dongying Formation, the Xian xian bulge has shrunk to the southeast corner. During the sedimentary period of the first member of Shahejie Formation to Dongying Formation, with the progress of the sedimentary process, the source of the Shenze low bulge in the southwest direction became stronger, and the source of the Xian xian uplift in the east and the Gaoyang low bulge in the northwest gradually weakened [13]. It is concluded that the sand body has been transported at a long distance, and the sedimentary area is located downstream of the river, which is a sedimentary environment of reduction-weak oxidation.

\section{Sedimentary structural features}

Sedimentary tectonic is a morphological difference due to the composition and structure of sediments, and is an important basis for discriminating sedimentary facies. Because structural bedding development is directly affected by sedimentation rate, water flow mode and climate conditions [14-17], different combinations of primary sedimentary structures are important means for inferring sedimentary environment and identifying sedimentary facies.

The single well phase diagram of L70-233 is divided into two parts vertically. The upper part of $3018-3038 \mathrm{~m}$ has the characteristics of the transition from delta to meandering river facies. The rock types are mainly gray fine sandstone and purple-red mudstone. Positive rhythm is dominant, and parallel stratification is visible. The lower $3038-3075 \mathrm{~m}$ reveals the sedimentary characteristics of the delta. The rock types are mainly large sections of brown fine sandstone and light gray fine sandstone. The fuchsia mudstone is thinner and mainly anti-rhythmic. Visible cross-bedding, parallel bedding and boulder-clay. The two parts are distinguished by obvious inflection points on the log curve. In the 3038-3075m coring section in the lower part, four types of sedimentary microfacies were encountered: underwater distributary channels, diversion between rivers, river mouth bar and mat sands (Figure 6).

\section{Particle size analysis}

When the sand body is deposited, its particle size distribution characteristics are determined by the hydrodynamic environment, and the sedimentary hydrodynamic environment is usually determined and analyzed by means of statistical analysis of the sandstone particle size in the study area [18]. By plotting the particle size probability curve of the study area, it is found that there are two main types of grain size probability curves for upper the first member of Shahejie Formation sandstone. The first type is a two-stage type: the content of suspended components is large, more than $35 \%$, and the slope is low, which is $35^{\circ}$. Only one segment was developed in the jump period, the sedimentary particle size was greater than $2.2 \varphi$, the slope was 55 $\circ$, the separation was better, and the intercept point with suspended components was $4.1 \varphi$. It reflects the hydrodynamic characteristics of stable sediments with reduced energy after entering the lake. Often represents the microfacies of an underwater shunt. The second type is the two-stage + transition section: it is mainly composed of a rolling population with a low slope $\left(44^{\circ}\right)$, a low content (7\%), a jumping population with a high slope $\left(68^{\circ}\right)$, and a suspension with a large content $(53 \%)$. The value of the particle size $\varphi$ of the intercept point of the jumping population and the floating population is about 4.1. Often represents the microfacies of the estuary dam (Figure 7).
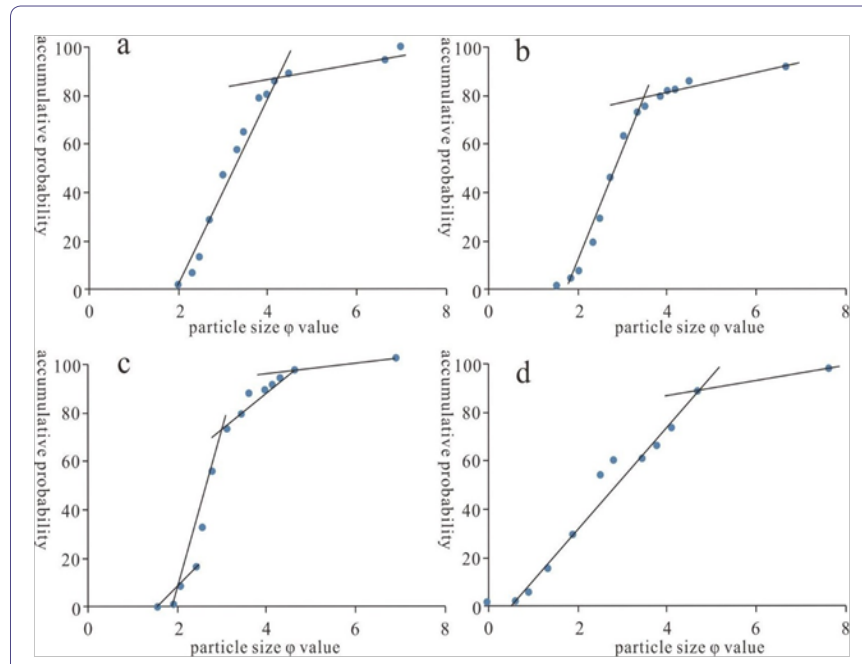

a L70-233 well 2859m; b L475 well 3234m; c L70-231 well 2937m; d L70-231 well $3066 \mathrm{~m}$

Figure 7: The grain size analysis diagram of Dawangzhuang Oilfield 
Citation: Fajun G, Shujuan Z, Xudong Y, Xiejun, Xiaoqin C, et al. (2019) Studying on the Sedimentary Control Function Affect by the Tectonic Evolution of Raoyang Sag in Upper the First Member of Shahejie Formation in Dawangzhuang Oilfield. J Atmos Earth Sci 3: 014.

\section{The sedimentary facies type}

According to the survey, the predecessors have different views on the types of sedimentary facies developed in the Dawangzhuang area. During the sedimentary period of the first member of Shahejie Formation in the Dawangzhuang area, Huang Zhijia et al. believed that the braided river delta depositional system was developed [2]. Zhu Mao et al. believed that the depositional system of shallow-water meandering river delta was developed [1]. Zhang Wei and others believed that the development of the braided river delta-lake depositional system [3]. Shi Lanting and others consider it a delta sedimentary system [19]. In addition, there are different opinions.

Research shows that the glutenite in the braided river sediment has high content, coarse lithology and more irregular grain size changes. The sediments in the reticulated channel are mostly filled with coarse debris. The color of mudstone in the sedimentary front of shallow water delta is characterized by purple-red and gray-phase, and almost no estuarine dam deposits are developed. The sandstone color in the terminal fan deposit is mainly light brown, and dark matter is rare in mudstone.

The study of lithology and particle size analysis in the study area found that the sandstone in the study area is mainly gray sandstone with fine grain size. The mudstones in upper the first member of Shahejie Formationare mainly gray, lacking the relevant features of braided rivers, reticulated rivers, shallow water deltas and terminal fan sedimentary facies. Therefore, this study believes that upper the first member of Shahejie Formation in the target area is dominated by delta front subfacies. The underwater diversion channel passes straight through the middle of the study area and extends from the southwest to the northeast. The estuary dam has a thick sand body, most of which is $6-9 \mathrm{~m}$, and is distributed on both sides of the river in a bead shape. Mat sand is widely distributed (Figure 8).

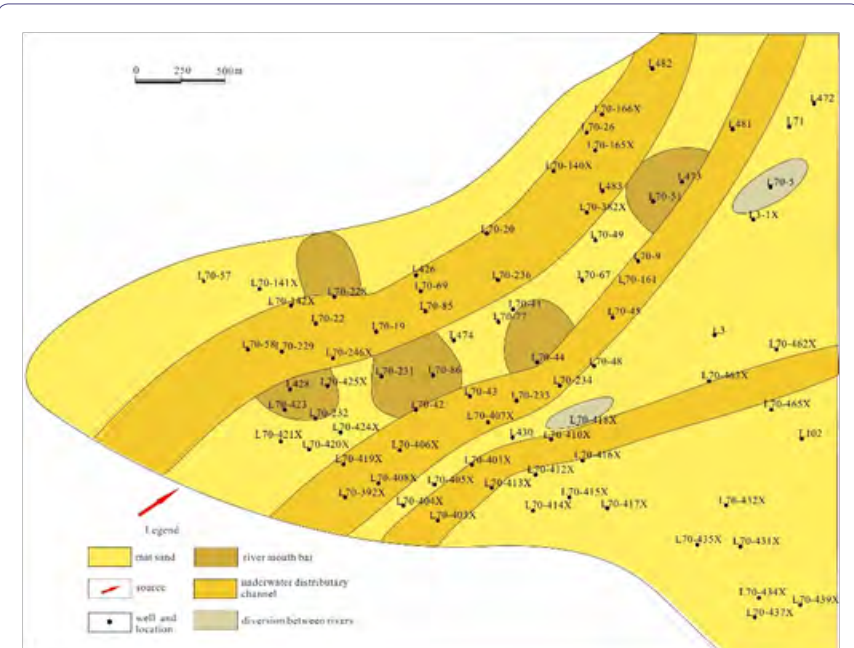

Figure 8: Plan of sedimentary microfacies of Es1uIV-2 small layers in Dawangzhuang area.

\section{Sedimentation Model}

The Raoyang sag experienced a process of multiple ascending and sinking. During the sedimentation of the lower first member of Shahejie Formation the lake water in the whole area was connected for the second time due to the expansion of the depression. The sedimentary period of upper the first member of Shahejie Formation to Dongying Formation belongs to the uplifting and extinction period of the fault depression in the Raoyang Sag. During the period of upper the first member of Shahejie Formation, the Xianxian uplift began to contract to the southeast, and the subsidence center moved northward to the area of Suning and Maxi depression.

Affected by the concave middle buried hill, the suning depression and the Dawangzhuang depression in the west, the provenance in the east and northwest is blocked, and the study area is mainly affected by the provenance of the Shenze low bulge in the southwest. At the same time, asthe terrain of Raoyang sag gradually flattened, lakes gradually disappeared, rivers continued to extend, and deltas continued to move forward. Delta facies was mainly developed in the study area during upper the first member of Shahejie Formation $\left(\mathrm{Es}_{1}{ }^{u}\right)$ period, and it was determined as a delta front sedimentary based on petrological characteristics (Figure 9).

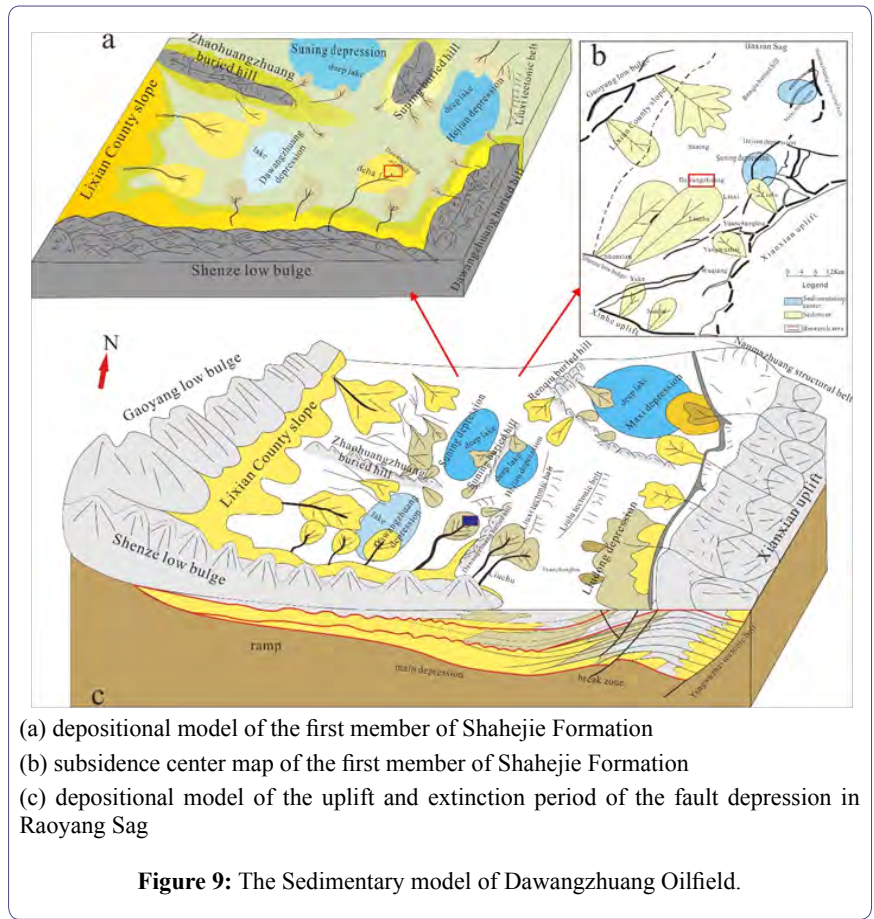

\section{Conclusion}

1. The Raoyang sag is in the period of sedimentation and extension in the sedimentary period of the lower first member of Shahejie Formation, which is the largest period of the lake formation, and the initial development of the Dawangzhuang buried hill. Upper the first member of Shahejie Formation was in the period of fault depression and extinction. The Lixian Slope was formed, and the buried hills such as Zhaohuangzhuang buried hills began to take shape. The subsidence center moved northward to Suning and Maxi depression, and blocked the supply of resources in the northwest and east. The Dawangzhuang area mainly accepts the provenance deposits of the southwestern Shenze low bulge during the sedimentary period of upper the first member of Shahejie Formation. 
Citation: Fajun G, Shujuan Z, Xudong Y, Xiejun, Xiaoqin C, et al. (2019) Studying on the Sedimentary Control Function Affect by the Tectonic Evolution of Raoyang Sag in Upper the First Member of Shahejie Formation in Dawangzhuang Oilfield. J Atmos Earth Sci 3: 014.

2. The rock types in the study area are mainly light gray fine sandstone and gray mudstone, indicating that the sedimentary environment was reduced-weakly oxidized. The sedimentary structures such as parallel bedding, cross- bedding and scouring surface developed under strong hydrodynamic conditions are common. Boulder-clay can be seen in fine sandstone.Based on the comprehensive petrological characteristics and particle size analysis, it is believed that the delta facies develops in the upper part of the first member of Shahejie Formation in the Dawangzhuang area and is further subdivided into the delta front subfacies. The determination of the sedimentary facies provides a powerful reference for the next exploration and development of the oilfield.

3. The sedimentary model map of the first member of Shahejie Formation in Dawangzhuang area was established to make the tectonic evolution process more intuitive.

\section{Reference}

1. Mao Z, Xiaomin Z, Hongliu Z,Yanlei D, Chang, et al. (2017) Depositional system of shallow-water meandering river delta: a case from the first member of Shahejie Formation in Zhaohuangzhuang-Suning area of Raoyang Sag, Jizhong Depression. Lithologic Reservoirs 29: 59-67.

2. Zhijia H (2014) The Research on Subtle Reservoir of the Dawangzhuang Area in The Raoyang Sag. China University of Geosciences.

3. Wei Z (2011)Research on Hydrocarbon Accumulation Characteristics of Paleogene Reservoirs in Dawangzhuang District of Raoyang Depression. China University of Petroleum.

4. Xiaoyuan W, Jiangbo H, Haifeng Y, Hui D, Li G, et al. (2018) Tectonic origin and evolution of Laibei low uplift and its control over sedimentary system. Journal of Northeast Petroleum University 42: 1-10+117.

5. Chao N, Youliang J (2006) Sequence stratigraphy and sedimentary system of the Paleogene Shahejie Formation in the Raoyang subbasin. Geology in China 33: 193-200.

6. Yuquan W, Jiafu Q, Ronghua Z, Quanyun M, Xinjie N, et al. (2018) Paleogene Deformation and its Control Mechanism in the Central Part of Raoyang Sag. Geotectonicaet Metallogenia 42: 628-638.

7. Fengxiang H, Jingwang L, Xiwei L, Yong W, Xin W, et al. (2017) Secondary exploration practice in Raoyang sag, Jizhong depression, Bohai Bay Basin. China Petroleum Exploration 22: 21-32.
8. Ruifeng Z (2006) Study on Sequence Stratigraphy and Subtle Reservoir Exploration of Paleogene in Raoyang Sag. Chinese Academy of Geological Sciences.

9. Fengming J (2007) Study on the Formation and Exploration of Subtle Reservoir in Fault Basin of Continental Facies. Chengdu University of Technology.

10. Jianning L, Chunpeng L, Kun L, Shao-chuan H, Kai P, et al. (2018) Control Factors of Mixed Sedimentation in First Member of Shahejie Formation in Lixian Slope. Journal of Hebei United university natural science edition 40: $37-41$

11. Jingxing G, Yiwen G (2018) Geochemical Characteristics and Geological Significance of Neogene System in Liuxi-Liubei Tectonic Zone in Raoyang Sag. Geological Science and Technology Information 37: 4149.

12. Jie X, Zaixing J (2019) Provenance analysis of clastic rocks: Current research status and prospect. Journal of Paleogeography 21: 379-396.

13. Yajun Z (2011) Study on Sequence Stratigraphy and Sedimentary System of Upper S to Dongying Formation in East Zhaohuangzhuang Area, Raoyang Depression. Chengdu University of Technology.

14. Gree S, Betal J (1990) A summary of exploration application of Sequence stratigraphy.GCSSEPM Foundation Eleven the Annual Research Conference Program and Abstract 320-327.

15. Hobson GD, Tiratsoo EN (1975) Introduction to Petroleum geology. Beacons Field:Scientific Press, USA Pg no: 21-50.

16. Hobson GD (1954) Some Fundamentals of Petroleum Geology.Oxford University Press, UK Pg no: 1-139.

17. Hobson GD, Tiratsoo EN (1983) Experimental and field investigations of sedimentation from turbidity currents.

18. Rui L, Dawei J, An L, Chang-hui G, Shi-min Z (2019) Comparison of Methods for Distinguishing Different Grades of Geomorphologic Surfaces Based on Sediment Particle Size Features Taking the Qingyijiang River Basin as An Example. Seismology and Geology 41: 837-855.

19. Lanting S, Qinlin Y, Dinghong Y, Guang-rong T, Jun D (2007) Sedimentary Evolution and Reservoir-Cap Rock Assemblages of Palaeogeue in Dawangzhang Area, Raoyang Sag, Central Hebei Province. Journal of East China Institute of Technology 2: 132-136. 


\section{II}

Journal of Anesthesia \& Clinical Care

Journal of Addiction \& Addictive Disorders

Advances in Microbiology Research

Advances in Industrial Biotechnology

Journal of Agronomy \& Agricultural Science

Journal of AIDS Clinical Research \& STDs

Journal of Alcoholism, Drug Abuse \& Substance Dependence

Journal of Allergy Disorders \& Therapy

Journal of Alternative, Complementary \& Integrative Medicine

Journal of Alzheimer's \& Neurodegenerative Diseases

Journal of Angiology \& Vascular Surgery

Journal of Animal Research \& Veterinary Science

Archives of Zoological Studies

Archives of Urology

Journal of Atmospheric \& Earth-Sciences

Journal of Aquaculture \& Fisheries

Journal of Biotech Research \& Biochemistry

Journal of Brain \& Neuroscience Research

Journal of Cancer Biology \& Treatment

Journal of Cardiology \& Neurocardiovascular Diseases

Journal of Cell Biology \& Cell Metabolism

Journal of Clinical Dermatology \& Therapy

Journal of Clinical Immunology \& Immunotherapy

Journal of Clinical Studies \& Medical Case Reports

Journal of Community Medicine \& Public Health Care

Current Trends: Medical \& Biological Engineering

Journal of Cytology \& Tissue Biology

Journal of Dentistry: Oral Health \& Cosmesis

Journal of Diabetes \& Metabolic Disorders

Journal of Dairy Research \& Technology

Journal of Emergency Medicine Trauma \& Surgical Care

Journal of Environmental Science: Current Research

Journal of Food Science \& Nutrition

Journal of Forensic, Legal \& Investigative Sciences

Journal of Gastroenterology \& Hepatology Research
Journal of Gerontology \& Geriatric Medicine

Journal of Genetics \& Genomic Sciences

Journal of Hematology, Blood Transfusion \& Disorders

Journal of Human Endocrinology

Journal of Hospice \& Palliative Medical Care

Journal of Internal Medicine \& Primary Healthcare

Journal of Infectious \& Non Infectious Diseases

Journal of Light \& Laser: Current Trends

Journal of Modern Chemical Sciences

Journal of Medicine: Study \& Research

Journal of Nanotechnology: Nanomedicine \& Nanobiotechnology

Journal of Neonatology \& Clinical Pediatrics

Journal of Nephrology \& Renal Therapy

Journal of Non Invasive Vascular Investigation

Journal of Nuclear Medicine, Radiology \& Radiation Therapy

Journal of Obesity \& Weight Loss

Journal of Orthopedic Research \& Physiotherapy

Journal of Otolaryngology, Head \& Neck Surgery

Journal of Protein Research \& Bioinformatics

Journal of Pathology Clinical \& Medical Research

Journal of Pharmacology, Pharmaceutics \& Pharmacovigilance

Journal of Physical Medicine, Rehabilitation \& Disabilities

Journal of Plant Science: Current Research

Journal of Psychiatry, Depression \& Anxiety

Journal of Pulmonary Medicine \& Respiratory Research

Journal of Practical \& Professional Nursing

Journal of Reproductive Medicine, Gynaecology \& Obstetrics

Journal of Stem Cells Research, Development \& Therapy

Journal of Surgery: Current Trends \& Innovations

Journal of Toxicology: Current Research

Journal of Translational Science and Research

Trends in Anatomy \& Physiology

Journal of Vaccines Research \& Vaccination

Journal of Virology \& Antivirals

Submit Your Manuscript: http://www.heraldopenaccess.us/Online-Submission.php 